\title{
Cinema and Philosophical Education: from Wittgenstein to Deleuze
}

\author{
Jūratė Baranova \\ Professor of the Department of Philosophy, \\ Lithuanian University of Educational Sciences \\ Ševčenkos 31-228, Vilnius, LT -03111 Lithuania \\ jurabara@gmail.com
}

\section{Abstract}

Bruce Russell argues, that cinema cannot create the philosophical knowledge for the reason that the answers to philosophical questions are contradictory and not obvious, the explicit argumentation is needed if the person is inclined to give justified answers to philosophical questions. Given examples are not satisfactory for philosophizing. On the other hand Slavoj Žižek, Stanley Cavell and Gilles Deleuze seems do not see this obvious gap between cinema and philosophy. They discuss the cinema as philosophy. What presumptions are needed for this approach? How this approach could be adapted in the philosophy education? 1

Keywords: cinema, philosophical education, Wittgenstein, Deleuze

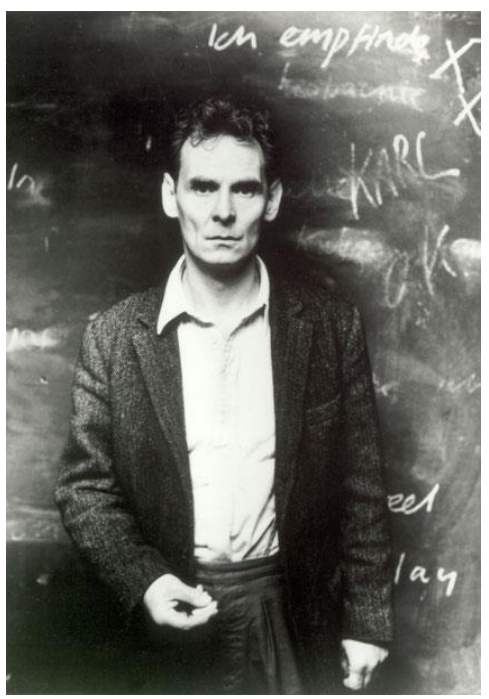

Wittgenstein as a professor at Cambridge University (staging Karl Johnson) in Derek Jarman film Wittgenstein (Wittgenstein, 1993) C) Bandung Productions

\footnotetext{
1 Tis study is based on the investigation included into the project 'Gilles Deleuze: Philosophy and Arts' financed by the Lithuanian Academy of Science (No. MIP-067/2014) 


\section{Wittgenstein and Deleuze as Cinema Goers}

The best movie about the philosophy and the philosophical education is Wittgenstein (1993) created by Derek Jarman's ${ }^{1}$. The script was written by Terry Eagleton. First of all, this movie shows Wittgenstein as a unique thinker, and only in the second place - as a whacky character or gay. Jarman did not make a mistake the Italian director Liliana Cavani made: in the film Beyond Good and Evil (1977) she created the personage of Friedrich Nietzsche only as an anecdotic character, having nothing to do with the turn in philosophical thinking the real Nietzsche had made. Jarman kept respect for the philosophical interests of real Wittgenstein and unusual form of the movie - as if the action is going in the opera theater or, speaking with Deleuze's concepts, in any-space-whatever - only enlarges an intellectual intrigue. In the film section Depression, the character-Wittgenstein refuses to go to the seminar. His friend Johnny reproaches him: 'What are you doing! Everyone's waiting for you'. Wittgenstein-character rejects: 'Go away. Please. They're torturing me'. Johnny insists, but Wittgenstein does not move. So Johnny uses his last argument: 'listen, just get through this seminar and we can go to the cinema' (Eagleton, Jarman,scs.27). In the Terry Eagleton's written script the insisting person is David Jarrett's and his tone is more strict: 'if you don't come out now I am not going to the flicks with you' (Eagleton, Jarman 1993:21). Wittgensteincharacter raises his head and complaining 'Intolerable, intolerable' moves to the seminar. Next shot: one sees him at the seminar. New episode: Wittgenstein with his friend sits in the cinema theatre and watches the movie. So cinema becomes a reward for difficulties in philosophy teaching. It is like an entertainment, an escape and has nothing to do with the philosophical teaching itself. 'There was no competition between cinema and seminar. I loved films', - reflects the character of Wittgenstein in the movie. - Especially Westerns and Musicals. Carmen Miranda and Betty Hutton were my favorite actresses. I always sat in the front row. Film felt like a shower bath, washing away the lecture. I hated the newsreels - far too patriotic' (Eagleton, Jarman, sc.30).

It is not common or necessary for a professional philosophy teacher to enjoy cinema. Even more: it is not a popular tradition to include cinema art into philosophy seminars. Some philosophy educators would always resist this idea. There can be several reasons. First of all: it is rather difficult to include the cinema into philosophical teaching for the reason that the image and the word, as revealed Belgian painter René Magritte and French philosopher Michel Foucault are as two heterogeneous series. Foucault in cooperation with Magritte in his book This is Not a Pipe discovered the innate incompatibility between the word and the image. Foucault noticed that Magritte discovered the gulf, "which prevents us from being both the reader and the viewer at the same time <...> " (Foucault 1983: 36). On the other hand, the use of film equipment in the audience requires additional training and flexibility in changing the rules of the teaching game and is always connected with the possible technical problems. But even more serious motive to resist to inclusion of the movies in philosophy teaching is the purity of profession. It starts from supposition, that the thought is always superior than the image and philosophy - superior to any art, and cinema as well. The idea starts from George Hegel, who indicated that in its development the Objective Spirit passes through three levels: art, religion and philosophy. The cinema is only an art. Philosophy as an abstract spirit is superior to visual thinking. The non-articulated supposition is that philosophy is connected to elite, but cinema - to popular culture. There is also the inertia of two thousand years old tradition. Cinema art takes its beginning only in the 20th century. The montage cinema was invented by the American film director Griffith David Llewelyn (1875-1948) in his three films The Birth of a Nation (1915); Intolerance (1916) and Broken Blossoms (1919). Soviet Russian film director and theorist Sergej Michailovich Eisenstein ${ }^{2}$ (1898-1948), was following Griffith and criticizing him. He paradoxically created two very important things: first of all, he created the basic ideological movies for Bolsheviks (Strike 1925, Battleship Potemkin, 1925, October, 1928) and helped to establish the Soviet regime. But, on the other hands his movies were examples of genial application of Hegelian dialectics to the sphere of cinema. Some years later started to flourish French and German school of cinema ${ }^{3}$. The French school is connected with the names of Jean Renoir (19241978), Jean Epstein (1897-1953), Abel Gance (1889-1981), Jean Vigo (1905-1934), Jean Grémillon (1901-1959), René Clair (1898-1981), Marcel Carné (1906-1996). The German-Austrian school was famous for expressionism. Her famous

\footnotetext{
${ }^{1}$ Michael Derek Elworthy Jarman (1942-1994) created movies Sebastiane (1976), Jubilee (1977), Caravaggio (1986), The Last of England (1988), War Requiem (1989), Edward II, (1991), Wittgenstein (1993), Blue (1993).

2 See Peter Greenaway's drama Eisenstein in Guanajuato (2015)

${ }^{3}$ Look: Kracauer, S. 1971. From Caligari to Hitler. A Psychological History of the German Film. Princeton: Princeton Univesity Press.
} 
directors were: Paul Wegener (1874-1948), George Wilhelm Pabst (1885-1967), Friedrich Lang (1890-1976), F.W.Murnau (1888-1954), Josef von Sternberg (1894-1969). To film classics belong also the films of Danish film director Carl Theodor Dreyer (1889-1968).

On the other hand, philosophy in general and the philosophy of education in particular start in Athens 5 centuries B.C. (Socrates, Plato, Aristotle schools). For twenty five centuries philosophers-educators managed to do without the cinema, relying on logic and critical thinking, verbal dialogue and text. It was not the philosophers who invented the cinema. And as usual it is very rare cases when cinema directors are reaching for philosopher's bachelor diploma. The professional prestige of philosopher arose beyond the cinema. Henry Bergson was the first who started to write about the cinema in the book The Creative Evolution, but his writings were critical. The cinema was already established in the beginning of the $20^{\text {th }}$ century, but the most eminent $20^{\text {th }}$ century film philosopher's reflected upon the phenomena of consciousness ignoring the cinema. Edmund Hussserl and Martin Heidegger never mentioned the cinema and Jean-Paul Sartre who wrote about imagination and the phenomena of consciousness in his books Imagination: A Psychological Critique (1936), The Imaginary (1940) also kept silence about the cinema. The first phenomenologist who started to compare phenomenology with the cinema was Maurice Merleau-Ponty in his book Phenomenologie de la perception (Deleuze 1983: 84). Merleau-Ponty tried to reveal the cinematic nature of phenomenological gestalts and came to the conclusion that at this point the limit is drawn beyond which the new psychology stats but the cinema remains ambiguous ally to philosophy (allie ambigu).

Analytic contra-argument against including the cinema into the philosophy teaching was were clearly formulated by Bruce Russell, who insisted, that the movies cannot create the philosophical knowledge for the reason, that the answers to philosophical questions are contradictory and not obvious, so the explicit argumentation is needed if the person intends to present justified answers to these questions. Only useful examples are not enough for philosophizing.

Nevertheless some philosophers attend cinema. The second after Wittgenstein famous philosopher who was happy going to cinema was French philosopher Gilles Deleuze (1925-1995). But, in contrast to Wittgenstein, for him cinema was not only an entertainment, but also a professional interest: he included cinema in his philosophical teachings and writings as well. Deleuze considered himself as a philosophy teacher with a very obvious metaphysical professional thinking. He wrote and published the books about philosophical classics: On David Hume, Friedrich Nietzsche, Immanuel Kant, Henri Bergson, Gottfried W. Leibnitz, Benedict Spinoza: Empirisme et subjectivité (Empiricism and Subjectivity,1953); Nietzsche et la philosophie (Nietzsche and Philosophy, 1962), La philosophie critique de Kant (Kant's Critical Philosophy ,1963), Le Bergsonisme (Bergsonism,1966), Nietzsche (in Pure Immanence 1965), Spinoza et le problème de l'expression (Expressionism in Philosophy: Spinoza,1968), Spinoza - Philosophie pratique (Spinoza: Practical Philosophy,1970, 2nd ed. 1981), Le pli - Leibniz et le baroque (The Fold: Leibniz and the Baroque,1988). His book Différence et répétition (1968) (Difference and Repetition) was based on a new Deleuzean anti-Kantian metha-psysics. In his early writings Deleuze also expresses his interest in literature and published the books: Proust et les signes (Proust and Signs,1964, 2nd exp. ed. 1976), Présentation de Sacher-Masoch (Masochism: Coldness and Cruelty,1967), Logique du sens (The Logic of Sense, 1969).

In 1969 Deleuze met Féllix Guattari and their intellectual cooperation ended with very important books: Capitalisme et Schizophrénie 1. L'Anti-CEdipe (Anti-Oedipus (1972); Kafka: Pour une Littérature Mineure (Kafka: Toward a Minor Literature,1975), Capitalisme et Schizophrénie 2. Mille Plateaux (A Thousand Plateaus,1987), Qu'est-ce que la philosophie? (What Is Philosophy?,1991).

But in addition to this in 1983 and 1985 Deleuze alone published two books devoted to cinema Cinéma I: L'imagemouvement (Cinema 1: The Movement-Image,1983); Cinéma Il: L'image-temps (Cinema 2: The Time-Image,1985). How it happed for philosopher to approach this new area of culture?

François Dosse in the book Gilles Deleuze \&Felix Guattari. Intersecting Lives in the chapter Deleuze Goes to the Movies step by step reveals the consequent turn of the philosopher toward the cinema. Deleuze was attending film programs organized by Cahiers, occasionally with his daughter Emilie, who had made films herself or with his wife, Fanny. The philosopher first spoke publicly about cinema in 1974, defending Hugo Santiago The Others. Deleuze also played the small role of the philosopher Lammenais in Michele Rosier film on George Sand, George qui? (George Who?, 1974) (Dosse 2010: 397- 405). 
What is the relation of philosophy and cinema? In Cinema 2. The Time-Image Deleuze answers: the good cinema, when it stops being bad is philosophy (quand il cesse d'être mauvais) (Deleuze 1985: 223) (Deleuze 1989: 166).

\section{Stanley Cavell: Uneventuful and Eventful Events}

The American philosopher Stanley Louis Cavell, the author of the books Must We Mean What We Say? (1969), The Claim of Reason: Wittgenstein, Scepticism, Morality and Tragedy (1979), The Pursuit of Happiness (1981) and etc. also saw the identity of film and philosophy. Rather distant from the philosophical suppositions of Deleuze, Cavell came to the same conclusion: films think and think philosophically.

Cavell says he was encouraged to turn to cinema as philosophy after he had attended the lectures of Austin who visited Harvard in 1955 and after he had read Wittgenstein. Wittgenstein not including movies into philosophy teaching formulated some ideas in his texts which encouraged the appearance of a new type of philosophy open to life and to cinema at the same time. Cavell reflected:

'I might specify three issues I recognize as exemplifying the kind of encouragement Austin and Wittgenstein lent to the progress of my thinking about film. One was allowing me to resist the idea of that relation of a photograph to what it is of is well through of as representation; another is the role of the ordinary, or say the uneventful, in the motion picture camera's interests in things, especially in the human face and figure; the third, most general, issue is their enabling me to feel that I was at once philosophizing and being responsive to, open to, the endless events (uneventful and eventful events, as it were) of film' (Cavell 2005: 168).

Wittgenstein's ideas enable Cavell to overcome the fear of the irrational which was in some way pervasive in western philosophy due to the popularity of such books as Alfred J. Ayer's Language, Truth and Logic. Mainly film philosophy can create an adequate vocabulary of passion. Starting from Wittgenstein's formulation from Philosophical Investigations: 'it is grammar that tells us what kind of object anything is', Cavell concludes that 'he is there claiming to satisfy, by educating, an ancient intellectual craving' (Cavell 2005: 195). This Wittgensteinian approach allowed to Cavell to the answer the question 'what is (the ontology of) film?' to formulate different type of questions, for example:

"what is the audience of film?'(as opposed to audiences of plays), 'what is the director of a film' (as opposed perhaps to the director of bank), 'what does the film screen screen?' (in contrast with what the support of a painting supports), 'what role does the script of a film play? (measured against what role the libretto of an opera plays), 'what counts as remembering a film? '(as compared with remembering a poem, or as novel, or an argument, or what happened yesterday), 'what is a remake of a film?' (as opposed to new production or a play), etc.'(Cavell 2005: 195)

The idea of Wittgenstein, that [in philosophy] we must do away with all explanation, and description alone must take its place' inspired Cavell to suggest a new type or quality of description suitable for teaching cinema. As usual in the Universities when grading students essays on cinema the assessment has two aspects: 'description' and 'analysis' and analysis is considered as more strong part of the essay. Cavell suggests for the students not to be afraid of descriptions and remember, that 'a serious film, like any work of art, resists interpretation, as it were insists upon being taken in its own terms $<\ldots>$ They are no more transparent to criticism than persons are' (Cavell 2005: 179).

Andrew Klevan, at this time lecturer in Film Studies at the University of Kent, discussed with Cavell the features of teaching cinema to the students. Their conversation can be summarized by several conclusions they came to:.1. Discussing a film with the students differs from discussing a painting, literature or music. In discussion a film one needs paraphrase. 2. Teaching cinema and learning the new type of description is very hard, it requires long discussions. 3. Teaching cinema has basic supposition: the inherent vulnerability of human being, its openness to tragedy. 4 . Teaching cinema requires the ability to tell a story. 5. To see film and to speak or write about it is mysteriously different things.6. A Film teaches when it strikes. Andrew Klewan remarked, that he always encourages his students to start write essay with a moment in film that struck them.

\section{Teaching Cinema as Philosophy}

In 1980 in Paris - VIII University started a curriculum of degree program in film and the film department having always excellent relations with philosophy department asked Jean-François Lyotard and Gilles Deleuze to oversee research in the 
film department. On November 10 1981, Deleuze gave his first lecture on cinema. He devoted to the film philosophy not only two books, but also three academic years and 250 class hours (Dosse 2010: 397). As notices Dosse, the microcosm at Vincennes were Deleuze gave lectures was completely unlike traditional academic universities. The new university, Paris-VIII, was a sort of anti-Sorbonne where multidisciplinarity was the religion: "at Paris-VIII no one taught traditional courses to prepare students for the national examinations, preferring instead to work on developing students' research skills. Lectures were for the most part banned in favor of open group discussions" (Dosse 2010: 344). Dosse also notices, that the intellectual path of Deleuze's Paris-VIII seminars is particularly rich and closely linked to his publications.

'He had an immediate rapport with his student audience, albeit without any concession concerning the highly philosophical content of his courses. His reputation as a fantastic teacher was well established in Paris even before he came to Vincennes, and he taught to a very large audience right from the start' Dosse 347)

After retirement in interview about philosophy Deleuze reflected about this period of lecturing as a major part of his own life. One of the possible secrets of Deleuze's popularity as a professor was his passionate involvement. Deleuze compared lecturing to a relatively fixed audience for a number of years to a research laboratory:

'you give courses on what you're investigating, not on what you know. It takes a lot of preparatory work to get a few minutes of inspiration. I was ready to stop when I saw it was taking more and more preparation to get a more taxing inspiration. And the future's bleak because it's becoming more and more difficult to do research in French universities' (Deleuze 1995: 139).

Deleuze suggested also the other comparison of teaching philosophy in non-traditional way: he compared it to the music: to the rock concert, where the listeners are from very multiple spheres: the first-year and nth-year students, students and non-students, philosophers and non-philosophers, young and old, and many different nationalities. There were always young painters and musicians there, filmmakers, architects. It seems Deleuze was fascinated by this multiplicity and did not see his aim as a philosophy professor of "building up knowledge" progressively. Philosophy teaching was not strictly scheduled: long sessions (in which, according to Deleuze, nobody took in everything, but everyone took what they needed or wanted, what they could use, even if it was far removed from their own discipline) were abrupt by interventions, often schizophrenic, 'then there was the taping phase, with everyone watching their cassettes, but even then there were interventions from one week to the next in the form of little notes I got, sometimes anonymously (Deleuze 1995: 139).

Deleuze used the charismatic way of teaching films as philosophy also philosophy in general as well. He did not believe in discussions for the reason that everyone is framing the problem in one's own way. He compared a discussion to an

'echo chamber, a feedback loop, in which an idea reappeared after going, as it were, through various filters. It was there that I realized how much philosophy needs not only a philosophical understanding, through concepts, but a non philosophical understanding, rooted in percepts and affects. You need both'(Deleuze 1995: 159).

Deleuze does not discern teaching cinema as philosophy from the other topics of philosophy for the reason he has a special approach to the heterogeneity of the word and the image. Gilles Deleuze and Félix Guattari discovered the unexpected sources of creativity namely in the heterogeneity and the territories in-between. In the book What is Philosophy? (Qu'est-ce que la philosophie? 1991) the philosophers discern the territory in-between uniting arts and philosophy. They suppose that art and philosophy crosscut the chaos and confront it, but it is not the same sectional plane. 'In the one there is the constellation of a universe or affects and percepts; and in the other, constitutions of immanence or concepts. Art thinks no less than philosophy, but it thinks through affects and percepts' (Deleuze and Guattari 1994: 66). The plane of composition of art and the plane of immanence of philosophy can slip into each other to the degree that parts of one may be occupied by entities of the other. In fact, in each case the plane and that which occupies it are like two relatively distinct and heterogeneous parts.

Philosophy is not a discussion, nor a meditation, nor contemplation. Philosophy is a creation of the new concepts, would say Deleuze and Guattari in their last book What is Philosophy? But first of all philosophy from Deleuzean point of view is a permanent experimentation. And this experimentation need openness to the life in general and to the arts in particular. Vision and word does not confront each other in education. They both meet. Where? And when? 


\section{The New Pedagogy of Perception}

Deleuze does not consider that cinema is going to be dangerous to the education based on the word and the argumentation. He discerns two possibilities of vision and extract the cinema from obsession with a technique. Deleuze in the Letter to Sergey Daney reflected upon the new pedagogy of perception connected to cinema, but also with TV. The philosopher responded to Daney's book La Rampe (1983). Deleuze was intrigued by the question posed in the book: What is there to see behind the image?' Reflecting upon the possible answer Deleuze discerned the new tendencies in the function of image:

'The relation between images and words, sounds, music changed too, with basic disymmetries between the aural and visual that allow the eye to read images, but also allow the ear to imagine the slightest noise. Finally, this new age of cinema, this new function of the image, was a pedagogy of perception, taking the place of an encyclopedia of the world that had fallen apart: a visionary cinema that no longer sets out in any sense to beautify nature but spiritualizes it in the most intense way. How can we wonder what there is to see behind an image (or following on from it. . .), when we can't even see what's in it or on the surface until we look with our mind's eye? And while we can identify many high points in this new cinema, it's the same pedagogical path that leads to all of them-Rosselini's pedagogy, 'a Straubian pedagogy, a Godardian pedagogy,' as you said in La Rampe, to which you now add Antonioni's pedagogy, by analyzing the eye and ear of a jealous man as a 'poetics' registering everything evanescent, everything that might disappear, a woman on the desert island in particular' (Deleuze 1995: 70).

But this new pedagogy of perception is threatened by the arousing interest on technique. Deleuze discerns possible sources of Daney's pessimistic point of view towards this new pedagogy of perception in the new approach towards the image:

'The question is no longer what there is to see behind the image, nor how we can see the image itself-it's how we can find a way into it, how we can slip in, because each image now slips across other images, "the background in any image is always another image," and the vacant gaze is a contact lens' (Deleuze 1995: 71).

Deleuze acknowledges that in this case, 'the encyclopedia of the world and the pedagogy of perception collapse to make way for a professional training of the eye, a world of controllers and controlled communing in their admiration for technology, mere technology', concludes Deleuze (Deleuze 1995: 72). How it is possible escape pressure of technology? Once again remains the question: What is there to see behind the image? What the lessons can be learnt in teaching cinema as philosophy? The answer would be looked for going through two Deleuze's books on cinema.

\section{Education Through Signs}

The Cinema 1. The Movement-Image starts from the warning, that it is not the history of cinema, but its taxonomy. It means that the reader is going to learn not about the periods of the history of cinema, but about the signs it deciphered.

The idea, that learning is essentially concerned with signs was for the first time expressed in Deleuze's book Proust and Signs (1964). The concept of sign was taken from Proust's book's final systematization that constitutes Time Regained (Le Temps Retrouve). Deleuze writes:

'Signs are the object of a temporal apprenticeship, not of an abstract knowledge. To learn is first of all to consider a substance, an object, a being as if it emitted signs to be deciphered, interpreted. There is no apprentice who is not "the Egyptologist" of something - One becomes a carpenter only by becoming sensitive to the signs of wood, a physician by becoming sensitive to the signs of disease. Vocation is always predestination with regard to signs. Everything that teaches us something emits signs; every act of learning is an interpretation of signs or hieroglyphs' (Deleuze 2000: 4).

Deleuze, following Proust, concludes that the signs are specific and constitute the substance of one world or another. In this plurality of worlds signs are not of the same kind, and they do not have the same way of appearing, do not allow themselves to be deciphered in the same manner, do not have an identical relation with their meaning. Deleuze deciphered four types of the world and four types of the signs in Proust's created literary universe: the worldly signs, the signs of love, the sensuous signs and the science of art. The researcher who is learning from signs is trying to grasp the essence, but it always escapes in the case of worldly signs, science of love and sensuous signs. One is able to reach the essence only on the level of art. 'But once they are manifested in the work of art they react upon all the other realms; we learn that they 
already incarnated, that they were already there in all these kinds. of signs, in all the types of apprenticeship (Deleuze 2000: 38).

In both volumes of Cinema Deleuze discerns much more different plurality of worlds and when mentioning sign he mentions that had taken this concept from American logician and pragmatist Charles Sanders Peirce. In Proust and Signs Deleuze connected the learning from signs with a search for an essence. In cinema philosophy the essence do not play role any more. The concept of sign is enabled to grasp to the most serious problems of philosophy, which bothered philosophical minds starting from Greek: the problem of movement and the problem of time. Cinema becomes as if a window one can look through to these problem from another perspective: from the sphere of moving images. Semiology of Peirce for Deleuze is like a skeleton for this new approach to the old philosophical problems. Henry Bergson idea of duration gives the vitality to the construction. Deleuze was impressed by Pierce's semiology for the reason that he wrote about signs on the basis of images and their combinations, not as a function of determinants which were already linguistic. Deleuze refers to Peirce's extraordinary classification of images and signs:

'Peirce begins with the image, from the phenomenon or from what appears. The image seems to him to be of three kinds, no more: firstness (something that only refers to itself, quality or power, pure possibility; for instance, the red that we find identical to itself in the proposition 'You have not put on your red dress' or 'You are in red'); secondness (something that refers to itself only through some - thing else, existence, action-reaction, effort-resistance); thirdness (something that refers to itself only by comparing one thing to another, relation, the law, the necessary)' (Deleuze 1989: 30).

Deleuze based this research schema in the first volume of Cinema 1. The Movement-Image on these firstness, secondness and thirdness of image, suggesting that these qualities correspond to the affection-image, the action-image and the relationimage. But, on the other hand, according to Deleuze, all three are deduced from the movement-image as material, as soon as it is related to the interval of movement. In this Deleuze's schema between the perception-image and the others, there is no intermediary, because perception extends by itself into the other images. But, in the other cases, there is necessarily an intermediary which indicates the extension as passage. This is why Deleuze suggested six, not three, types of perceptible visible images: 'perception-image, affection-image, impulse-image (intermediates between affection and action), action-image, reflection-image (intermediate between action and relation), relation-image' (Deleuze 1989: 32)

On the other hand Deleuze considers that he takes the term 'sign' in a completely different way from Peirce:he considers that sign is a particular image that refers to a type of image, whether from the point of view of its bipolar composition, or from the point of view of its genesis. So he constructs his own classification of signs. In the second volume of Cinema: The Time-Image Deleuze poses to Peirce the testing question: why does Peirce think that everything ends with third ness and the relation-image and that there is nothing beyond?(Deleuze 1989:.33). Deleuze steps beyond and finds

'signs which, eating away at the action-image, also brought their effect to bear above and below, on perception and relation, and called into question the movement-image as a whole: these are opsigns or sonsigns. We could no longer consider Peirce's thirdness as a limit of the system of images and signs, because the opsign (or sonsign) set everything off again, from the inside' (Deleuze 1989: 34).

\section{How a Character is Learning the New Vision of Reality?}

Cavell and Deleuze were not cooperating in teaching cinema as philosophy. They do not practice philosophical friendship and created two indispensable schools of teaching cinema as philosophy. They were separated by the space, by different cultures, by different educational background and, as noticed D.N.Rodowick, "seem only dimly aware of one another" (Rodowick 2010: 98). They were interested into different movies. In the book The Pursuit of Happiness: The Hollywood Comedy of Remarriage Cavell reflected upon the Holywood's 'golden age' remarriage comedies'. Cavell was interested in the moral lessons of these movies revealing a necessity in order to preserve one's happiness to grow up together with one's partner. The man in order to grow with a woman partner has to acknowledge the woman's autonomy, and for her to see that he acknowledges it. Only by doing so will he make himself worthy of her, so that she may at last give herself to

\footnotetext{
1 The Lady Eve (1941, director Preston Sturges), It Happened One Night (1934, director Frank Capra), Bringing Up Baby (1938, director Howard Hawks), The Philadelphia Story (1940, director George Cukora), His Girl Friday (1940, director Howard Hawks), Adam's Rib (1949, director George Cukora), The Awful Truth (1937, director Leo McCarey).
} 
him for the second time (remarry him). Cavell concluded that these films teach that the pursuit of happiness require not to fulfill our desires but to transform them.

Deleuze mentioned more than four hundred movies in his two volumes of Cinema. He showed respect for American cinema reflecting upon the historical movies, created by Cecil DeMille. He reflected a lot upon Orson Welles's (1925-1985) creation: Citizen Kane (1941); The Lady from Shanghai (1947), discussed the principles of new New York cinema school in John Cassavetes (1929-1989) films: Faces, Love Streams, Shadows, Woman Under the Influence. On the other hand his selected stream of favorite 'good movies' was mostly from European cinema: Andrei Tarkovsky (The Mirror, Solaris, Stalker), Kryzstof Zanussi, Joseph Losey (1909-1984) (The Servant, 1963), Alain Resnais (Last Year at Marienbad, 1961; My American Uncle), Federico Fellini (And the Ship Sails On, 1983), Michelangelo Antonioni (1912-2007) (The Night, 1961), Max Ophüls (The Earrings of Madame de..., 1953), Luis Bunuel (1900-1983) (Belle de jour, 1967, The Discrete Charm of the Bourgeoisie, 1972), Lucino Visconti (Leopard, Sandra, Senso, White Nights, Obsession, Death in Venice, Damned, Conversation Piece), Werner Wenders (State of Things) etc. Besides, Deleuze showed interest also in Japanese movies, e.g. Akira Kurosawa (1910-1998) (Rashomon, 1950), etc.

Cavell was looking for the education of new emotions in cinema, Deleuze was seeking the birth of the new thought. Notwithstanding their distance, D.N. Rodowick indicated some common points between Cavell's and Deleuze's approaches to cinema: inclination towards moral reasoning. Cavell was concerned with the problem of ethics in film and philosophy, above all through his characterization of an Emersonian moral perfectionism. Rodowick discerned in Cavell's Emersonian ethics echoes with Gilles Deleuze's Nietzschean and Bergsonian perspectives on cinema, 'wherein concepts of movement and time are related as the expression of belief in the world and its powers of transformation' (Rodowick 2010: 98).

As important bridge between Deleuze's and Cavell's approach to cinema Rodowick indicated first of all their mutual interest in Nietzsche. Another common point is their original way of asking ethical questions in ontological contexts:

'Though Cavell uses the word frequently, and Deleuze rarely, both evalute ontology as a particular approach to Being. This is not the being or identity of film or what identifies film as art, but rather, the ways of being that art provokes in us - or more deeply, how film and other forms of art express for us or return to us our past, current, and future states of being. Also, in both philosophers, the ethical relation is inseparable from our relationship to thought. For how we think, and whether we sustain a relation to thought, are bound up with our choices of a mode of existence and our relations with others and to the world' (Rodowick 2010: 99).

Cavell takes interest more in our relations with others, Deleuze - to the world. Cavell reflecting upon remarriage comedy tried to reveale at first sight not given and it seems unsignificant aspects of our relations with others and showed, that

'we help and hurt and interest, and bore each other in our everyday lives in countless unremarked and fateful ways, that while we have to learn to tolerate clumsiness in one another - say inadvertent, heedless, thoughtless, careless slaps in our ignorant or uneducated responses to frustration - we have also to learn not to tolerate slugs, meaning any one of a hundred ways we have of dealing out little deaths of rejection' (Cavell 2005: 203).

Cavell discerns one common feature uniting film with philosophy: 'they are both preoccupied with ways in which we miss our lives, miss the density of significance passing by in a film, in or speech, in our lives' (Cavell 2005: 206).

Deleuze notices one common feature between philosophy and cinema: they both say something about the encounter of the subject with reality. The cinema subject - its main character -- does not ask a philosophical question: why there is something instead of nothing. She/he experiences the other problem: how to withstand something which is unbearable and unthinkable in reality. Modern cinema invents new signs and breaks old sensory-motor schemes based on a movement. Modern cinema turns from action to a purely optical and sound situation:

'It makes us grasp, it is supposed to make us grasp, something intolerable and unbearable. Not a brutality as nervous aggression, an exaggerated violence that can always be extracted from the sensory-motor relations in the action-image. Nor is it a matter of scenes of terror, although there are sometimes corpses and blood. It is a matter of something too powerful, or too unjust, but sometimes also too-beautiful, and which henceforth outstrips our sensory-motor capacities' (Deleuze 1989: 18).

This intolerableness of reality is something like what existentialists or Albert Camus were writing about. Deleuze does not articulate the problem in detail in existentialist manner, he simply states it as a main fact of human existence that the cinema 
is revealing even more clearly than philosophy is. Romantics were able to grasp the intolerable-or the unbearable, the empire of poverty. They also produced the new means of knowledge and action: the visionary approach to reality. Deleuze is relying on romantics' experience.

Deleuze pays no attention to the actors playing the characters, he almost never mentions their names, he only indicates, that 'a new type of actor was needed: not simply the non-professional actors that neo-realism had revived at the beginning, but what might be called professional non-actors, or, better, 'actor-mediums', capable of seeing and showing rather than acting, and either remaining dumb or undertaking some never-ending conversation, rather than of replying or following a dialogue' (Deleuze 1989: 20). As a matter of fact when discussing the type of the character - clairvoyant, who is reflecting the encounter with the something unbearable in reality and is learning to see the reality from a new side, becoming a visionary Deleuze usually returns to the characters of three women: Karin in Roberto Rossellini's Stromboli, Irene in Rossellini's Europe'51 and Gertrud in Carl Theodor Dreyer's Gertrud (1964). The first two - Karin and Irene - was played by Ingrid Bergman (1915-1982), who suggested to Rossellini to create common movie Stromboli (1950). In this film Bergman plays Karin, a displaced Lithuanian in Italy, who escapes the internment camp by marrying an Italian soldier and fisherman (acting Mario Vitale), whom she met in the camp on the other side of the barbed wire. After marriage they went to his home island of Stromboli. She tries to adapt to the very harsh and barren environment of the island and to very traditional and conservative people -- hostile and strange, -- but she failed. She becomes pregnant and understands that in any case she has to escape. In escape plan she has to pass the hill with volcano and at this very moment the volcano starts to erupt. Karin has no possibility to go further, but she also has no possibility to return. She goes asleep and when gets awakened reflects her new situation. The film documentary features real segments about fishing tuna and an actual an eruption of the volcano. Most villagers are played by actual people from the island. Notwithstanding some skeptical acceptance of the film from the side of film critics, Deleuze considers this movie as an example of the modern cinema, when all sensory-motor schemes are broken and the character reflects the world in the new optical and sound situation and learns the things she/he never saw before. Karin becomes visionary when she suddenly understands the extraordinary greatness of reality she is not able to bear on. Deleuze writes:

'Stromboli presents a foreign woman whose revelation of the island will be all the more profound because she cannot react in a way that softens or compensates for the violence of what she sees, the intensity and the enormity of the tunny fishing ('It was awful ...'), the panic-inducing power of the eruption ('I am finished, I am afraid, what mystery, what beauty, my God ... .')' (Deleuze 1989: 2).

Deleuze concludes that island Stromboli' beauty is too great for Karin so becomes intolerable, but also for all the spectators, like too strong a pain. But mainly the greatness of the situation as something unbearable in the reality possibly revealed in the movies engenders the real unforgettable philosophical lessons in cinema. On the other hand something unbearable is experienced when the heroine Gertrud (acting Nina Pens Rode) from Dreyer's movie Gertrud (1964) also experiencing the difficulties in marriage and the relations with other lovers is reflecting in her mentality her own life. Gertrud becomes conscious of belief as thought of the unthinkable (,Have I been young? No but I have loved. Have I been beautiful? No but I have loved. Have I been in life? No but I have loved.' (Deleuze 1989: 170-171).

This a limit-situation was repeated in the other movie Europe 51 created by Rossellini in which Ingrid Bergman also played the main role of, in Deleuze words, bourgeois woman Irene. Living in wealthy family with industrialist man George (acting Alexander Knox) Irene (acting Bergman) is too busy with her social life and the parties they are giving at home to their friends. So she has no enough time left for her their son Michele (acting Sandro Franchina) and Irene does not notice his loneliness and his longing for her attention. During a dinner party, Michele constantly tries to get his mother's attention, but Irene is more interested in being a good hostess to her guests. Michele attempts suicide by falling several stories down a stairwell. At the hospital, Irene promises to never leave Michele, but he dies. Irene overcomes her depression and grief and starts to notice the poor people and take care of them, donating her money. She's horrified by the factory's working conditions, which she sees as slavery. Irene then cares for a prostitute who is dying of tuberculosis. Her family, husband and mother are not able to understand the reason of her absence from home and conclude she is betraying the family and is mentally ill, so close her in mental institution. The very important is the end the movie. Irene has to make her final choice, as a heroine from Kierkegaard's Either/Or. She is suggested by her family to decide: either to return to the family and keep on going to live a life as she lived before, or she will stay in mental hospital, forever closed. The people she has helped, along with many she hasn't, were standing outside her cell window, praying to her as their new 'patron saint.' She made a decision to stay with these people and maintain forever closed for the reason she learnt unforgettable lessons about herself 
and reality she is living in she can not betray any more. She behaves like Knight Myshkin or Sonia Marmaladova from Dostoyevsky's novel The Idiot. Rosselllini was expressing his admiration to Saint Francis of Assisi values. For Deleuze Irene as well as Karin from Stromboli becomes as a sign of clairvoyance, a new visionary.

'These are pure seers, who no longer exist except in the interval of movement, and do not even have the consolation of the sublime, which would connect them to matter or would gain control of the spirit for them. They are rather given over to something intolerable which is simply their everydayness itself. It is here that the reversal is produced: movement is no longer simply aberrant, aberration is now valid in itself and designates time as its direct cause. 'Time is out of joint': it is off the hinges assigned to it by behaviour in the world, but also by movements of world. It is no longer time that depends on movement; it is aberrant movement that depends on time. The relation, sensory-motor situation indirect image of time is replaced by a non-localizable relation, pure optical and sound situation direct time-image. Opsigns and sonsigns are direct presentations of time. the grasping of the intolerable even in the everyday and insignificant' (Deleuze 1989: 170)

One can notice essential difference in the lessons learnt in remarriage comedies, discussed by Cavell and the lessons learnt by Deleuze's clairvoyants - Karin, Gertrud and Irene. Three Deleuze's beloved woman -visionaries never remarry. On the contrary, they start to learn the new lessons about reality only when they are leaving husbands or other lovers and start to go their own way. Visionary is alone and cares not about the relations with other people, but about the vision itself.

\section{Conclusions}

1. When philosopher goes to cinema it is possible that he has no any other interest except of entertainment, as it was it Wittgenstein's case and is revealed in the best movie about philosophy teaching Wittgenstein created by Derek Jarman.

2. On the other hand the philosophical ideas of Wittgenstein inspired American film philosophy school created by Stanley Cavell.

3. When philosopher goes to cinema it is possible that his intention for entertainment coincides with his professional interest, as happened in French philosopher's Gilles Deleuze' case, who lectured cinema in university and wrote two books on cinema.

4. Lecturing cinema as philosophy demands the new conception of philosophy elaborated by Cavell (philosophy as responsiveness) and Gilles Deleuze (philosophy as experimentation) .

5. Cavel and Kevin came to a conclusion that lecturing cinema as philosophy has several features: 1. Discussion about a film with the students differs from discussing a painting, literature or music. In discussion a film one needs paraphrase. 2. Teaching cinema and learning the new type of description is very hard, it requires long discussions. 3. Teaching cinema has basic supposition: the inherent vulnerability of human being, its openness to tragedy. 4 . Teaching cinema requires the ability to tell a story.

5. To see film and to speak or write about it is mysteriously different things.6. A Film teaches when it strikes.

6. Deleuze in teaching practice preferred the conception of charismatic teaching without any strict rules in advance.

7. Deleuze in his works elaborated the pedagogy of perception and education through signs.

8. Cavell and Deleuze discerned the possibility for characters to learn from their own experience when meeting a limitsituation. But in Cavell's film philosophy the possibility to learn from one's experience is left for both partners and the possibility of happiness is sustained in remarriage. In contrast to it Deleuze in film philosophy is reflecting not happiness but a clairvoyance. When all the links with the men partners are broken women are able to understand something unbearable in reality itself.

\section{Literature}

[1] Bogue, R. 2003. Deleuze on Cinema. New York, London: Routledge. 
[2] Bogue, R. 2010. To Choose to Choose - to Believe in This World, in Afterimages of Gilles Deleuze's Film Philosophy, ed. D. N. Rodowick. Minneapolis and London: University of Minnesota Press: 115-134.

[3] Bowen, P. 1993. In the Company of Saints. Derek Jarman's Wittgenstein and Beyond. Filmmaker. The Magazine of Independent Film, vol. 2, no. 1 http://www.filmreference.com/Directors-Ha-Ji/Jarman-Derek.html

[4] Cavell, S. 1969. Must We Mean What We Say? New York: Charles Scribner's Sons.

[5] Cavell, S. 1979. The Claim of Reason. Wittgenstein, Scepticism, Morality, and Tragedy. New York, Oxford: Oxford University Press.

[6] Cavell, S. 1996 a. The Same and Different: The Awful Truth, in The Cavell Reader, ed Stephen Mulhall. Cambridge, Mass.; Oxford, UK: Blackwell: 167-198.

[7] Cavell, S. 1996 b. Psychoanalysis and Cinema: The Melodrama of the Unknown Woman, in The Cavell Reader, ed Stephen Mulhall. Cambridge, Mass.; Oxford, UK: Blackwell: 221-252.

[8] Cavell, S., Klevan, A. 2005. What Becomes of Thinking on Film? Stanley Cavell in Conversation with Andrew Klevan, in Film as Philosophy. Essays in Cinema After Wittgenstein and Cavell, eds. R. Read, J. Goodenough. Macmillan, Palgrave: 167-209.

[9] Deleuze, G. 1983. Cinéma 1. l'Image-mouvement. Paris: Les éditions de minuit.

[10] Deleuze, G. 1985. Cinéma 2. l'Image-temps. Paris: Les éditions de minuit.

[11] Deleuze, G. 1986. Cinema 1. The Movement-Imag, trans. Hugh Tomlinson and Barbara Habberjam, Minneapolis: University of Minnesota Press.

[12] Deleuze, G.1989. Cinema 2. The Time-Image, trans. Hugh Tomlinson and Robert Galeta, Minneapolis: University of Minnesota Press.

[13] Deleuze, G.1990a. The Logic of Sense, Constantin V.Boundas (ed), trans.Mark Lester and Charles Stivale, New York: Columbia University Press

[14] Deleuze, G.1990b. Negotiations, 1972-1990, trans.Martin Joughin, New York: Columbia University Press.

[15] Deleuze, G., Guattari F.1994. What is Philosophy? trans. Hugh Tomlinson and Graham Burchell, New York: Columbia University Press.

[16] Deleuze, G. 1994. Difference and Repetition, transl. Paul Patton, London and New York: Continuum.

[17] Deleuze, G. 2000a. Proust and Signs, trans.Richard Howard, Minneapolis, MN: University of Minnesota Press.

[18] Deleuze G. 2000b. "The Brain is the Screen: An Interview with Gilles Deleuze" // The Brain Is the Screen. Deleuze and the Philosophy of Cinema. Ed. Gregory Flaxman, Minneopolis and London: University of Minnesota Press, p. 365-374

[19] Dosse, F.2010. Gilles Deleuze \& Felix Guattari. Intersecting Lives. New York: Columbia University Press.

[20] Eagleton, T., Jarman, D. 1993. Wittgenstein. The Terry Eagleton Script. The Derek Jarman Film. London: British Film Institute.

[21] Fischer, L. 2004. Film Editing. In A Companion to Film Theory. Ed.T.Miller, R.Stam. Oxford: Blackwell Publishing.p. 64-83.

[22] Goodenought, J. 2005. Introduction I: A Philosopher Goes to the Cinema, in Film as Philosophy. Essays in Cinema After Wittgenstein and Cavell, eds. R. Read, J. Goodenough. Macmillan Macmillan, Palgrave: 1-28.

[23] Kovacs A.B. 2000. The Film History of Thought. In The Brain Is the Screen. Deleuze and the Philosophy of Cinema. Ed. Gregory Flaxman, Minneopolis and London: University of Minnesota Press, p.153-170.

[24] Kracauer, S. 1971. From Caligari to Hitler. A Psychological History of the German Film. Princeton: Princeton Univesity Press.

[25] Livingston, P. 2009. Cinema. Philosophy, Bergman. On Film as Philosophy. Oxford: Oxford University press.

[26] Rodowick, D. N. 2010. Ethics. The World, Time, in Afterimages of Gilles Deleuze's Film Philosophy, ed. D. N. Rodowick. Minneapolis and London: University of Minnesota Press: 97-114.

[27] Ropars-Wuilleumier, M.-C. 2010. Image or Time? The Thought of the Outside in The Time-Image (Deleuze and Blanchot), in Afterimages of Gilles Deleuze's Film Philosophy, ed. D. N. Rodowick. Minneapolis and London: University of Minnesota Press: 15-30.

[28] Sobchack V. 1992. The Address of the Eye. A Phenomenology of Film Experience. Princeton: University Press. 